\title{
Project SOAR Supporting Disadvantaged Students' Technology Needs
}

Diane H. Jackman, (E-mail: djackman@niu.edu), Northern Illinois University Nina G. Dorsch, (E-mail: ndorsch@ niu.edu), Northern Illinois University

\begin{abstract}
Project SOAR was developed to support the technology needs of financially or physically disadvantaged students or minority students who are actively engaged in a teacher certification program.
\end{abstract}

\section{BACKGROUND}

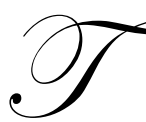

Che state of Illinois is experiencing a shortage of teachers as evidenced by the number of emergency certificates that are issued by the state each year, particularly in high-need teaching areas and high-need (often urban) school districts. In addition, teacher candidates who are completing teacher education programs do not necessarily reflect the ethnicity of the students they are teaching. A goal of many colleges and universities is to recruit and retain minority students in teacher education. Unfortunately, some minority students enter colleges and universities unprepared for college and at-risk of not completing a college education. These underprepared students need additional support in order to succeed in college.

Pitts and White (1996) interviewed faculty to determine the issues and problems associated with unprepared students and possible responses to help under prepared students succeed. Their findings are consistent with previous studies. Unprepared students require more time on the part of the faculty to learn basic course content because of a lack of basic reading and writing skills. Some faculty felt they had to lower standards to accommodate unprepared students while others provided outside 'remedial' instruction. Many faculty indicated that they became more flexible in their approach to teaching and were more creative in their instruction. Administrative support and structures were seen as important to the success of unprepared students.

In a report to the California Community College Board of Governors (2002), several strategies that were found to be effective with at-risk students were one-on-one tutoring, workshops, and technology availability. Boylan (2002) indicates that tutoring is one of the most universal services and that well-trained tutors are essential. While tutoring works for some students and some areas, group workshops and supplemental instruction are the techniques that work better for others.

Learning communities have been used more often with unprepared and at-risk students. These communities offered peer support and faculty committed to undergraduate education and tend to lessen the fragmentation of the college curriculum. Tinto's (1997) research supported the use of learning communities for college students. More recent findings reiterate the positive effects of student participation in learning communities. For example, a comprehensive review of Lindblad in 2000 (as cited by Stassen, 2003) suggests that students in learning communities have "greater institutional commitment, greater intellectual development and opportunity to analyze and integrate ideas, greater tolerance for difference and appreciation for pluralism, and demonstrate higher persistence and academic performance as measured by college grade point average (GPA)." (p. 583).

Technology was viewed as playing an increasingly important role in education and college students were expected to know how to use a variety of technologies. Robinson (1996) found that free peer tutoring, and assuring 
access to the computer could be effective in working with at-risk students. Robinson (1996) indicated that computer skills will be needed in most fields in the future. Project SYNERGY was described as one program which addressed unprepared students and helped them gain necessary technology skills. Computers and their use were critical to assist the unprepared student in catching up and being successful in college. Schultz (2000) noted that the use of computers in courses was becoming more common. Since that time, the use of technology has increased tremendously inside and outside the classroom. Professors are becoming more adept at using the computer. Many have developed on-line courses or partial on-line course while others have students submit all assignments electronically. In essence, computer skills are increasingly necessary for student access to virtual learning communities within courses and across institutions.

\section{Program Components}

\section{Mary F. English Technology Award}

The Mary F. English Technology Award was established in September 2000 to assist the College of Education in recruiting and retaining students who are financially or physically disadvantaged, in a teacher education program at Northern Illinois University. Recipients of the award receive a computer and printer for their personal use plus basic supplies each semester. Award guidelines include: enroll as a full-time student at Northern Illinois University, possess a 2.5/4.0 GPA or higher, be enrolled in a teacher education program, and have two years left before graduation. In addition, each applicant is asked to submit a one page paper describing their financial need or physical disadvantage.

\section{Project SOAR - Educational Technology Support Project}

The Educational Technology Support Project was established to recruit, retain, and support multicultural preservice teachers. The primary goal of project was to increase the ranks of technologically competent multicultural teachers in the state of Illinois. The College of Education at Northern Illinois University targeted multicultural students pursuing educational programs who were recipients of the Mary F. English Technology Award and provided additional technology support along with classroom integration ideas. Funds to support this program were received from a long-term Higher Education Cooperation Act grant from the state of Illinois. These funds were used to provide additional support by enabling each student to acquire the necessary training, mentoring activities, and supplies, as well as other support services needed for proficiency with computer technology for teaching as well as continuing their education.

\section{Objectives}

Project SOAR - the Educational Technology Support Project focused on the following objectives:

1. Assist the College of Education to recruit multicultural students for teacher education programs and provide them with a computer and printer for their educational and personal use.

2. Support project participants and participating institutions by providing assistance for appropriate computer supplies, collaborative planning and teaching, and mentoring activities.

3. Assist the College of Education to retain multicultural students and provide them with the opportunity to become familiar with and to utilize computers as a learning, teaching, and informational tool as outlined in the Illinois State Board of Education for All Teachers (6/01/2003) through continuous training most appropriate and effective for the teaching profession.

\section{PROGRAM ACTIVITIES}

Several activities were implemented which corresponded with the goals and objectives surrounding recruitment, support, and training for the project's participants. The activities included: 
- recruitment of nominees for the Mary F. English Technology Award and recruitment of graduate students for training purposes and technical support.

- initial training and orientation.

- group technology workshops based on topics significant to educational professionals.

- one-on-one technology training sessions.

- mentoring.

- dissemination of new technology trends through magazine publications, newsletters, etc.

- attendance at a technology conference.

\section{Recruitment of Nominees/Recipients}

In each year of the three year grant, ten to fifteen multicultural students at Northern Illinois University received the Mary F. English Technology Award, bringing the three year total to 40 awards. Letters of invitation with the application were sent to all minority students indicating a major in teacher education. In addition, advisors were notified, posters were placed near teacher education classrooms, and small advertisements were placed in the student newspaper.

Graduate students were recommended by their departments. They submitted a cover letter indicating their interest in the program along with their resume. Each potential candidate went through an interview process.

\section{Initial Training and Orientation}

The project director, two graduate assistants, and the technology coordinator worked collaboratively to provide training, computer maintenance, personal support, and technical support for the students in the program during all three years of the program.

All Mary F. English Technology Award recipients received their computer equipment sometime during the fall semester, usually in October. Before installing the equipment in the recipients' residences, a mandatory orientation to the program and training session occurred. Basic functions of the computer hardware and software were introduced and the technological abilities of each recipient were assessed. Graduate assistants discovered that recipients had a fundamental knowledge of computers and a basic knowledge of selected pieces of software. Each year, workshops were planned to build on the recipient's current skills and knowledge.

\section{Group Technology Workshops}

The technology workshops that were offered during each year, were based on state and national standards for technology knowledge, skills, and use by teacher education students. Workshop topics were revised on a regular basis in order to assure that student needs were being met, standards were being met, and topics reflected the most current applications and research in the field. Workshops covered the following areas: spreadsheets, word processing, desktop publishing, web publishing, presentation graphics, educational software, telecommunication, and information access. Many recipients would repeat workshops in succeeding years just to learn new techniques that were being taught. Each session could accommodate up to 30 students, and when not filled with English recipients, the sessions were opened to other teacher education students. On average, one workshop was held each week for a total of 25/50 workshops each semester/year.

\section{One-on-one Technology Sessions}

For many students, group workshops on technology topics were not the most appropriate learning environment. In order to accommodate the diverse learning styles of our students, one-on-one workshops were offered on fundamental topics for technology-proficient teachers and to support new skills acquired through workshops. Oneon-one sessions were available through scheduled $1 / 2$ hour appointments or as walk-in appointments if tutors were available. The one-on-one tutors were the graduate assistants who facilitated the workshops and were well aware of student needs. 


\section{Technology Conference}

Mary F. English Technology Award recipients attended the Illinois Technology Conference and participated in the pre-sessions and conference workshops. About one-half of the recipients took advantage of this as the grant funding supported their attendance.

\section{Mentoring}

Face-to-face mentoring sessions were arranged and linked new Mary F. English Technology Award recipients with previous recipients. This allowed students the opportunity to help each other and work collaboratively with educational technology. After the mentoring pairs had met and established a good working relationship, they were encouraged to use technology to work collaboratively. The amount of support given to mentoring activities decreased over the years as the grant funds were concentrated on technology integrations skills for the classroom. The project director and educational technology coordinator used both Blackboard and electronic mailings as a means of communication and mentoring of students. Information about workshops, new technology integration techniques, new technology, etc., was shared.

\section{POPULATION}

The population served in this project included disadvantaged and multicultural students enrolled in teacher education at Northern Illinois University. Priority was given to recipients of the Mary F. English Technology Award. Forty students were named Mary F. English Technology Award recipients and 26 of those students were ethnic minorities.

During each year of the grant, over 150 students participated in one-on-one tutoring sessions. Each technology workshop offered over the three years accommodated up to 25 students per session. Most of the sessions had 20 - 22 students enrolled. Workshop numbers were higher than the actual program enrollment since they were opened to the general student population

\section{PROGRAM EVALUATION}

A variety of evaluative instruments/techniques were employed to determine the effectiveness of the program to include the following:

1) Reflection and Feedback from Program Participants - Recipients of the Mary F. English Technology Award participated in small group meetings where they verbally expressed their satisfaction or dissatisfaction with regard to the Educational Technology Support Program. They reflected on their experiences and provided recommendations for improvement.

2) Evaluation Forms - Workshop and one-on-one session participants completed evaluation forms to determine the usefulness and effectiveness of the training they received.

3) Written Test of Technology Competencies - Mary F. English Technology Award recipients were required to complete the technology competency test to determine their knowledge and skill level relative to each competency taught through one-on-one sessions and group workshops. Upon successful completion of the test, the student received a Certificate of Technology Competency listing all of the areas in which competency was achieved.

\section{PROGRAM RESULTS}

During the three years of this grant, $100 \%$ of Project SOAR - the Educational Technology Support Program participants rated the overall effectiveness of the one-on-one programs to be "outstanding" or "very good" and the workshops to be "excellent" or "good." The participants regarded their technology training to be very useful, and continued to attend other workshops or one-on-one sessions sponsored by the grant and by the university. Participants noted that they were becoming more comfortable with technology and were discovering unique ways to incorporate it 
into their clinical experiences and student teaching. Recipients were encouraged to see personal progress in technology skills from semester to semester.

All recipients who graduated were proficient in the Written Test of Technology Competencies and received the certificate detailing their technology skills and competencies. Each of the graduates credited the support, workshops, and one-on-one technology sessions for their knowledge and use of technology. The portfolios developed by these graduates showcased their use of appropriate technology in the classroom and in the creation of the portfolio.

\section{Outcomes Related to Grant Objectives}

Objective 1: Assist the College of Education at NIU to recruit multicultural students from teacher education programs and provide them with a computer and printer for their educational and personal use.

Funding from a private donor provided up to 10 computers each year for at-risk and needy students. During each year of the grant, there were more worthy applicants than awards available. Over the course of the three years, forty students received grants. Each year saw more minority students competing for this Mary F. English Technology Award. At the end of the three years, close to one-third of the Mary F. English Technology Award awardees were minority students.

Objective 2: $\quad$ Support project participants and participating institutions by providing assistance for appropriate computer supplies, collaborative planning and teaching, and mentoring activities.

Each of the participants in this program received a "set amount" of computer supplies each semester based on the budget allocation. In addition, technology workshops and one-on-one sessions were offered to Mary F. English Technology Award awardees providing the cutting edge technology skills. Participants in the workshops and one-one-one sessions indicated that all the sessions were valuable, both personally and professionally, and rated them as "excellent" or "very good." The mentoring activities were minimally successful because of the lack of funding in the latter years of the grant and the need to focus efforts on technology competence and integration skills.

Objective 3: Assist the College of Education to retain multicultural students and provide them with the opportunity to become familiar with and to utilize computers as a learning, teaching, and informational tool as outlined in the Illinois State Board of Education for All Teachers (6/01/2003) through continuous training most appropriate and effective for the teaching profession.

Ten students, $25 \%$, successfully completed their program and graduated during the past three years. Two students, $5 \%$, failed to maintain a minimum grade point average and were academically dismissed and seven, and $17.5 \%$, changed their majors and left the program. While this last figure may be disturbing, it is important to remember that many of the technology skills learned by these students of color are essential in today's world and are transferable to most other academic majors. The rest of the students remained enrolled in a teacher education program.

The variety of technology workshops that were available to Mary F. English Technology Award awardees provided training that was geared to national and state standards that must be met by all teachers. Participants who have graduated and completed the Written Test of Technology Competency Exam possess appropriate technology skills as evidenced by the $100 \%$ pass rate.

The extra support provided by the grant funds has been essential in the Mary F. English Technology Award academic career. It has provided an opportunity for these individuals to have access to technology and learn the latest skills. Comments from the students indicate a sincere appreciation for their computer and printer and the time spent with grant personnel in technology workshops. Without this added support, many of these students indicated that they may not have been able to pursue their educational goals and/or gain the appropriate technology skills. 


\section{FUTURE PLANS}

The Mary F. English Technology Award program and Project SOAR - Educational Technology Support Project is being continued this year with funding from the College of Education and a new Higher Education Cooperation Act grant from the state of Illinois. Mary F. English Technology Award recipients have increased from 10 to 15 students, an increase of 5 students from past years. This increase in students would not have been possible without the additional support from outside donors. The basic technology workshops are continuing and will be open to all teacher education students.

During the past three years, we found that many students do not possess basic technology skills and could benefit from extra assistance. Graduate assistants have been hired and are conducting a wide variety of technology workshops. As enrollment in teacher education programs increase, so will the number of technology workshops offered. During the past three years, it has been observed that the recipients are coming to teacher education programs with more refined technology skills. This will change the types and number of technology workshops offered as will the technological changes happening every day.

\section{REFERENCES}

1. Academic Senate for California Community Colleges. (2002). A survey of effective practices in basic skills. Sacramento: California Community Colleges, Board of Governors. (ERIC Document Reproduction Service No. ED479522).

2. Boylan, H. R. (2002). What works: Research-based best practices in developmental education. Boone, NC: Continuous Quality Improvement Network with the National Center for Developmental Education.

3. Pitts, J. M. White, W.G., Jr. (1996). The impact of underprepared students on regular college faculty. Paper presented at the Second National Conference on Research in Developmental Education. (ERIC Document Reproduction Service No. ED411724).

4. Robinson, S. (1996). Underprepared students. (ERIC Document Reproduction Service No. ED433876).

5. Schultz, C. (2000). Remedial education: Practices and policies in community colleges. Washington, DC: American Association of Community Colleges.

6. Stassen, J. L. (2003). Student outcomes: The impact of varying living-learning community models. Research in Higher Education, 44(5).

7. Tinto, V. (1997). Classrooms as communities: Exploring the educational character of student persistence. Journal of Higher Education, 68(6), 599-623. 